Received: 1 October 2018

Revised: 15 October 2018

Accepted: 12 November 2018

Published: 30 December 2018

\title{
Analisis Kepuasan Pelanggan Atas Kualitas Produk dan Pelayanan Dengan Metode SEM-PLS
}

\author{
Besse Arnawisuda Ningsi ${ }^{1, \text { a) }}$,Lucia Agustina ${ }^{2, \text { b) }}$ \\ IProgram Studi Matematika, Fakultas Matematika dan Ilmu Pengetahuan Alam, Universitas Pamulang \\ 2Program Studi Matematika, Fakultas Matematika dan Ilmu Pengetahuan Alam, Universitas Pamulang
}

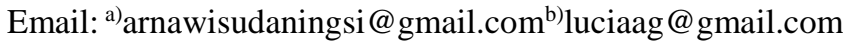

\begin{abstract}
This study aims to analyze what factors can affect customer satisfaction and to estimate customer satisfaction models for Bleached Cotton products. Respondents in this study were Bleached Cotton customers. The variables used consist of customer satisfaction variables (Y) as dependent variables and independent variables namely product quality $(\mathrm{X} 1)$ and service quality $(\mathrm{X} 2)$ with each variable will be measured by the indicator. The sample in the study was taken as simple as 33 people. The instrument used in this study as a means of collecting virgin using questionnaires / questionnaires. This questionnaire is used to measure the customer satisfaction index. Statements are prepared using a Likert scale with five respondents' answers to customer satisfaction, namely: Strongly Agree (SS), Agree (S), Doubt (RR), Disagree (TS) and Strongly Disagree (STS). The data analysis technique used is Partial Least SquareStrutural Equation Modeling (PLS-SEM) which is used to predict and develop theories. Based on the results of the analysis, it was found that product quality has an effect on customer satisfaction, which means that not all customers will feel satisfied if only with the quality of the product, but there must be other factors. In this study the most positive indicators of production quality so that customer satisfaction can be achieved are performance indicators. While indicators that are less influential on the quality of production causing customer satisfaction to be achieved are indicators of design. Service quality has an effect on customer satisfaction, which means that the higher and better the quality of service provided, it can ensure customer satisfaction can be achieved. The first positive most influential indicator of service quality so that customer satisfaction can be achieved is the assurance indicator. And indicators that are less influential on the quality of production so that customer satisfaction is not achieved is an indicator of empathy. Product quality and customer service can simultaneously influence customer satisfaction so that if these two variables are prioritized, customer satisfaction will be achieved more optimally. Product quality and customer service are measured using indicators of design, performance, conformance, tangiable, emphaty, responsiveness, reliability, assurance are factors that influence customer satisfaction because when viewed from the output obtained.
\end{abstract}

Keywords: Customer Satisfaction, Product Quality and Service, SEM - PLS.

\section{Abstrak}

Penelitian ini bertujuan untuk menganalisis faktor-faktor apa saja yang dapat mempengaruhi kepuasan pelanggandan untuk membuat estimasi model kepuasan pelanggan atas produk Bleached Cotton. Responden dalam penelitian ini adalah pelanggan Bleached Cotton. Variabel yang di gunakan terdiri dari variable kepuasan pelanggan $(\mathrm{Y})$ sebagai variabel terikat dan variabel bebas yaitu kualitas produk $\left(\mathrm{X}_{1}\right)$ dan kualitas pelayanan $\left(\mathrm{X}_{2}\right)$ dengan masing-masing variable akan di ukur oleh indikator. Sampel dalam 
penelitian diambil secara acak sederhana sebanyak 33 orang. Instrumen yang digunakan dalam penelitian ini sebagai alat pengumpulan dara menggunakan angket/kuesioner. Angket ini digunakan untuk mengukur indeks kepuasan pelanggan. Pernyataan disusun menggunakan skala Likert dengan lima jawaban responden terhadap kepuasan pelanggan yaitu : Sangat Setuju (SS), Setuju (S), Ragu-ragu (RR), Tidak Setuju (TS) dan Sangat Tidak Setuju (STS). Teknik analisis data yang digunakan adalah Partial Least Square-Strutural Equation Modelling (PLS-SEM) yang digunakan untuk memprediksi dan mengembangkan teori. Berdasarkan hasil analisis diperoleh bahwa Kualitas produk berpengaruh terhadap kepuasan pelanggan yang artinya tidak semua pelanggan akan merasa puas jika hanya dengan kualitas produk, melainkan harus ada faktor lain. Pada penelitian ini indikator yang paling berpengaruh positif terhadap kualitas produksi sehingga kepuasan pelanggan dapat tercapai adalah indikator performance. Sedangkan indikator yang kurang berpengaruh terhadap kualitas produksi sehingga menyebabkan kepuasan pelanggan kurang tercapai adalah indikator design. Kualitas pelayanan berpengaruh terhadap kepuasan pelanggan yang artinya semakin tinggi dan baik kualitas pelayanan yang diberikan maka bisa di pastikan kepuasan pelanggan dapat tercapai. Indikator yang paling berpengaruh positif pertama terhadap kualitas pelayanan sehingga kepuasan pelanggan dapat tercapai adalah indikator assurance. Dan indikator yang kurang berpengaruh terhadap kualitas produksi sehingga menyebabkan kepuasan pelanggan kurang tercapai adalah indikator emphaty. Kualitas produk dan pelayanan pelanggan secara bersamaan dapat berpengaruh terhadap kepuasan pelanggan sehinga jika kedua variabel ini di utamakan, maka kepuasan pelanggan akan tercapai lebih maksimal. Kualitas produk dan pelayanan pelanggan yang diukur menggunakan indikator design, performance, conformance, tangiable, emphaty, responsiveness, reliability, assurance merupakan faktor-faktor yang mempengaruhi kepuasan pelanggan.

Kata-kata kunci: Kepuasan Pelanggan, Kualitas Produk dan Layanan, SEM - PLS.

\section{PENDAHULUAN}

Fenomena universal yang terjadi di dunia bisnis dalam era global saat ini adalah perusahaan selalu dihadapkan dengan situasi kompetisi yang semakin menajam, baik dalam pasar domestik maupun di pasar internasional.

Menurunnya tingkat kepuasan pelanggan kepada perusahaan sebagian besar disebabkan oleh menurunnya pelayanan dan mutu dari produk yang dihasilkan. Hal ini disebabkan oleh persepsi pelanggan terhadap produk yang dihasilkan oleh perusahaan. Banyak produsen (perusahaan) yang gagal dalam memberikan kepuasan bagi pelanggan, hal ini disebabkan karena produsen (perusahaan) tidak mengaplikasikan prinsip dasar marketing atau sumber diferensiasi dalam marketing. Sumber diferensiasi dalam marketing dibedakan menjadi 3. kelompok, yaitu : price driven, product driven,dan pelanggan driven. Kelompok price driven mengutamakan faktor harga sebagai tolak ukur dalam menentukan produk yang akan dipilihnya. Akibatnya para produsen (perusahaan) dengan sengaja membuang tambahan atau bonus dengan digantikan potongan harga (diskon). Kelompok product driven sangat mengutamakan keunikan (keunggulan fitur) produk atau jasa yang ditawarkan. Sedangkan kelompok pelanggan driven mengutamakan kualitas pelayanan. Apabila ketiga kelompok diferensiasi marketing sudah terpenuhi oleh perusahaan, maka pelanggan akan merasa puas dalam membeli produk yang ditawarkan oleh perusahaan.

Penelitian ini akan menilai kepuasan pelanggan terhadap pembelian produk Bleached Cotton pada pelanggan dalam pasar International. Bleached Cotton merupakan salah satu produk PT Argo Manunggal Triasta yang mempunyai banyak keunggulan dibandingkan dengan produk lainnya. Beberapa keunggulan Bleached Cotton adalah 100\% Kapas., Tingkat Absobant : 10S, Penampilan : Bright White (Putih) dan Netral. Panjang Serat : 14-18 mm (di banding dengan produk lain yang seratnya pendek). Tingginya intensitas Pelanggan dalam pemakaian Bleached Cotton akan memberikan informasi yang cukup banyak dan akurat untuk mengukur kepuasan pelanggaran dalam penggunaan produk tersebut.

Berdasarkan latar belakang tersebut maka penulis tertarik untuk melakukan penelitian dengan judul "Analisis Kepuasan Pelanggan Atas Kualitas Produk dan Pelayanan Dengan Metode SEM- PLS". 


\section{METODE}

Variabel Penelitian

Variabel adalah suatu konsep tentang atribut ataupun sifat yang terdapat pada subjek penelitian yang beraneka ragam secara kuantitatif maupun kualitatif. Variabel dalam penelitian ini terdiri dari variable bebas (independen) yaitu Kualitas Produk $\left(\mathrm{X}_{1}\right)$, Kualitas Pelayanan $\left(\mathrm{X}_{2}\right)$ dan variabel terikat (dependen) yaitu Kepuasan Pelanggan (Y).

Tabel 1. Variabel dan Indikator Penelitian

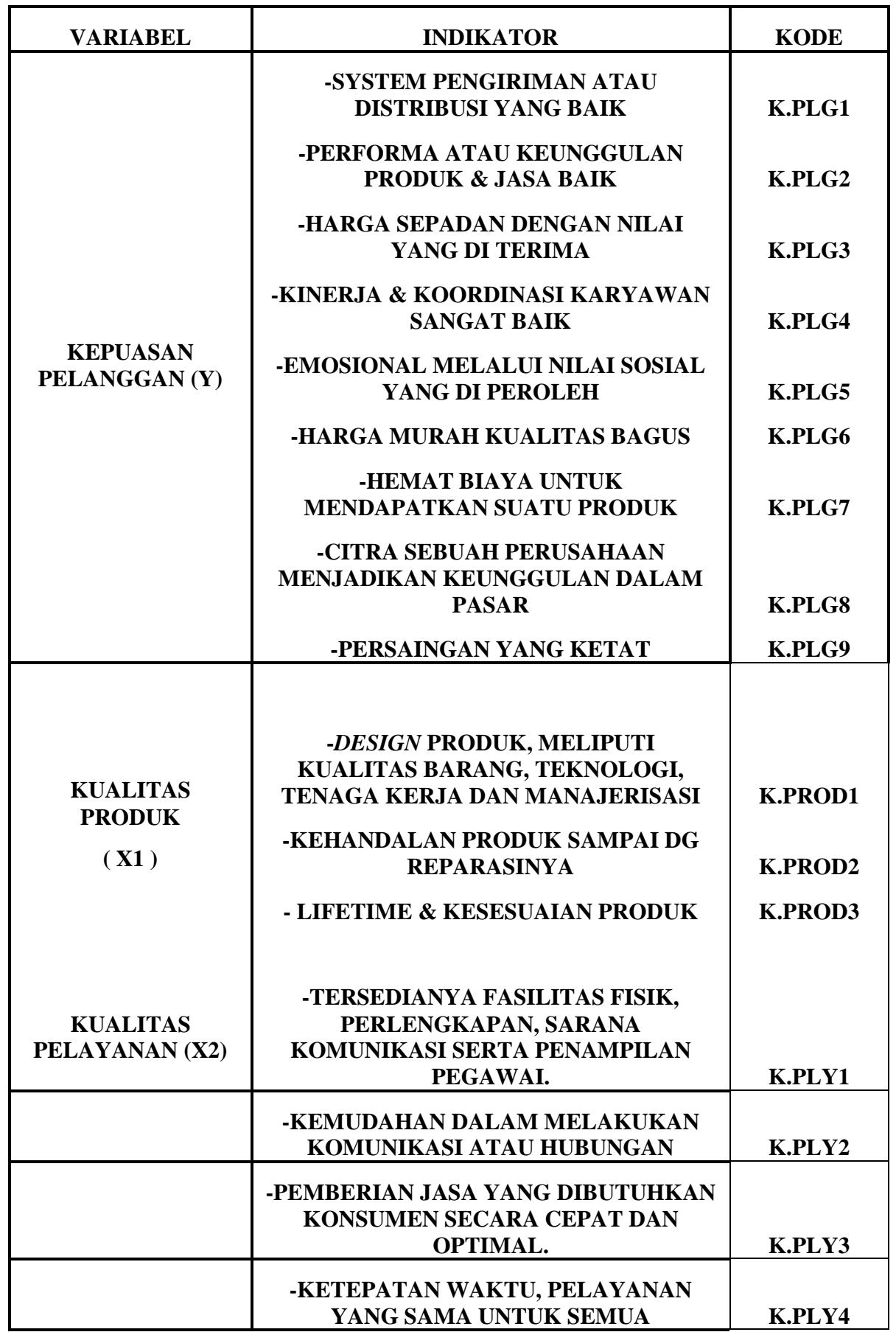




\begin{tabular}{|l|c|c|} 
& PELANGGAN TANPA KESALAHAN & \\
\hline & $\begin{array}{l}\text {-PENGETAHUAN DAN KEMAMPUAN } \\
\text { SERTA KESOPANAN YANG DIMILIKI } \\
\text { KARYAWAN. }\end{array}$ & \multirow{2}{*}{ K.PLY5 } \\
\hline
\end{tabular}

\section{Tempat dan Waktu Penelitian}

Penelitian dilaksanakan selama empat minggu di kantor PT Argo Manunggal Triasta yang bertempat di JL. MH Thamrin Km 4, Cikokol, Tangerang - Banten. Penelitian dilakukan pada jam operational kantor yakni hari Senin sampai Jumat dari pukul 08:00 sampai dengan pukul 17:00.

\section{Populasi dan Sampel}

Menurut Sugiyono (2007: 55) populasi merupakan wilayah generalisasi yang terdiri atas objek atau subjek yang mempunyai kualitas dan karakteristik tertentu yang ditetapkan oleh peneliti untuk dipelajari dan kemudian ditarik kesimpulannya. Selanjutnya, Arikunto (2002: 102) menjelaskan bahwa populasi merupakan keseluruhan subjek penelitian. Populasi dalam penelitian ini adalah pelanggan Bleached Cotton.

Menurut Sugiyono (2007: 55), sampel merupakan bagian dari jumlah karakteristik yang dimiliki oleh populasi yang digunakan. Bila populasi besar, dan peneliti tidak mungkin mempelajari semua yang ada pada populasi misalnya karena keterbatasan dana, tenaga dan waktu, maka peneliti dapat menggunakan sampel yang diambil dari populasi itu. Apa yang dipelajari dari sampel tersebut, kesimpulannya akan dapat diberlakukan untuk populasi. Sampel dalam penelitian ini mengambil secara acak pelanggan tetap dan aktif lebih dari 1 tahun sebanyak 33 pelanggan.

\section{Teknik Pengumpulan Data}

Instrumen yang digunakan dalam penelitian ini sebagai alat pengumpulan dara menggunakan angket/kuesioner. Angket ini digunakan untuk mengukur indeks kepuasan pelanggan. Kuesioner adalah sejumlah pertanyaan tertulis yang digunakan untuk memperoleh informasi dari responden, Arikunto (2002:128). Pernyataan disusun menggunakan skala Likert dengan lima jawaban responden terhadap kepuasan pelanggan yaitu : Sangat Setuju (SS), Setuju (S), Ragu-ragu (RR), Tidak Setuju (TS) dan Sangat Tidak Setuju (STS). Semakin tinggi skor yang diperoleh maka semakin tinggi indeks kepuasan pelanggan, sebaliknya semakin rendah skor yang peroleh maka semakin rendah pula indeks kepuasan pelanggan.

\section{Teknik Analisis Data}

Structural Equation Modelling (PLS-SEM)

SEM adalah salah satu bidang kajian statistika yang dapat digunakan untuk mengatasi masalah penelitian, dimana peubah bebas maupun peubah respon adalah peubah yang tak terukur. SEM dapat menguji secara simultan sebuah rangkaian hubungan yang relatif sulit terukur. Hubungan yang dimaksud adalah hubungan yang dibentuk dari salah satu atau lebih peubah bebas dengan satu atau lebih peubah tidak bebas. Peubah-peubah tersebut dapat berupa peubah laten yaitu peubah yang tidak dapat diukur secara langsung, yang terbentuk dari beberapa peubah penjelas/manifes, yaitu peubah yang dapat diukur secara langsung.

SEM terdiri dari dua model yaitu model struktural dan model pengukuran. Model struktural memperlihatkan struktur kausalitas antar peubah laten, sedangkan model pengukuran digunakan untuk mendukung peubah laten yang dikonfirmasikan oleh dimensi-dimensi peubah penjelas. Salah satu teknik analisis SEM adalah SEM berdasarkan pada covariance (CBSEM) dan SEM berbasis komponen atau variance (PLS). 
SEM berbasis covariance dikembangkan pertma kali oleh Joreskog (1973), Keesling (1972), dan Wiley (1973). SEM berbasis covariance mendapatkan popularitasnya setelah tersedianya program LISREL. Dengan menggunakan fungsi Maximum Likelihood (ML), covariance based SEM (CBSEM) berusaha meminimumkan perbedaan antara kovarians sampel yang diprediksi oleh model teoritis sehingga proses estimasi menghasilkan matriks kovarians dari data yang diobservasi.

Sebagai alternatif CBSEM, pendekatan variance based atau component based dengan Partial Least Square (PLS) orientasi analisis bergeser dari menguji model kausalitas/teori ke component based predictive model. PLS dapat menganalisis sekaligus konstruk yang dibentuk dengan indikator refleksif dan indikator formatif.

PLS adalah salah satu metode alternatif yang dapat menjawab masalah diatas karena PLS adalah metode lunak atau soft model yang didalam perhitungannya tidak memerlukan asumsi yang ketat, baik mengenai sebaran dari peubah pengamatan maupun dari ukuran contoh, yang tidak harus besar. Metode lain yang dapat digunakan adalah LISREL yaitu metode yang dalam perhitungannya memerlukan sebaran data berdistribusi normal dan ukuran contoh harus besar $(n>100)$. Oleh Joreskog dan Wold (1982) PLS dikembangkan sebagai metode umum untuk pendugaan model laten (peubahpeubah laten) yang diukur secara tidak langsung oleh peubah penjelas.

PLS-SEM digunakan untuk memprediksi dan mengembangkan teori. Hal ini berlainan dengan SEM yang berbasis kovarian yang ditujukan untuk menguji teori yang ada dan konfirmasi. Disamping itu, PLS-SEM juga digunakan untuk memprediksi variabel laten endogenous atau mengidentifikasi variabel-variabel utama jika riset merupakan riset eksploratori atau perluasan suatu teori struktural yang ada. Dengan meningkatnya keingintahuan para peneliti tentang analisis hubungan non linier baik dalam penelitian sosial, bisnis ataupun dibidang sistem informasi, menjadikan PLS sebagai aplikasi yang tepat untuk pencarian solusi terkait masalah yang ada. Aplikasi seperti ini juga akan sangat membantu para mahasiswa untuk menentukan desain penelitian dan teknik analisis, khususnya statistika sebagai alat ketika berhadapan dengan maslaah dan atau pertanyaan saat penelitian.

SEM dengan PLS digunakan untuk memprediksi dan mengembangkan teori. Hal ini berlainan dengan SEM yang berbasis kovarian yang ditujukan untuk menguji teori yang ada dan konfirmasi. Disamping itu, PLS SEM juga digunakan untuk memprediksi variabel laten endogenous atau mengidentifikasi variabel-variabel utama jika riset merupakan riset eksploratori atau perluasan suatu teori struktural yang ada.

Model analisis jalur semua variabel laten dalam PLS terdiri dari tiga set hubungan : (1) Inner model yang menspesifikasikan hubungan antar variabel laten, (2) Outer model yang menspesifikasi hubungan antara variabel laten dengan indikator atau variabel manifesnya, (3) Weight relation dalam mana nilai kasus dari variabel laten dapat diestimasi.

Persamaan inner model adalah :

$$
\begin{aligned}
& \eta_{j}=\beta_{0 j}+\gamma_{o j}+\sum_{i} \beta_{j i} \xi_{i}+\sum_{i} \gamma_{j i} \eta_{i}+\zeta_{j} \\
& \text { dengan asumsi : } E\left(\zeta_{j}\right)=0, E\left(\xi_{i} \zeta_{j}\right)=0, E\left(\eta_{i} \zeta_{j}\right)=0 \\
& \text { dimana : }
\end{aligned}
$$

j : banyaknya peubah laten

$\eta_{j} \quad$ : peubah laten tidak bebas ke-j

$\eta_{i} \quad$ : peubah laten tidak bebas ke-i untuk $\mathrm{i} \neq \mathrm{j}$

$\beta_{j i}:$ koefisien lintas peubah laten eksogen ke-i ke variabel laten endogen ke-j

$\gamma_{j i}:$ koefisien lintas dari peubah laten endogen ke-i ke variabel laten endogen ke-j

$\beta_{j 0}:$ intersep

$\zeta_{j} \quad$ : kesalahan pengukuran (inner residual) variabel laten ke-j

i : banyaknya lintasan dari peubah laten bebas ke peubah laten tak bebas

Membangun hubungan antara sekumpulan indikator dengan variabel latennya. Outer model mengacu kepada model pengukuran. Ada tiga cara membangun hubungan antara indikator dengan variabel laten, yaitu hubungan refleksif, hubungan formatif, dan MIMIC (Multiple Effect Indicators 
for Multiple Causes). Model ini juga mendefinisikan bagaimana setiap blok indikator berhubungan dengan variabe latennya dengan persamaan sebagai berikut :

$$
\begin{aligned}
& x=\Lambda_{x} \xi+\varepsilon_{x} \\
& y=\Lambda_{y} \eta+\varepsilon_{y}
\end{aligned}
$$

Dimana $\mathrm{x}$ dan $\mathrm{y}$ adalah indikator atau manifest variabel untuk variabel laten eksogen dan endogen $\xi$ dan $\varepsilon$, sedangkan $\Lambda_{x}$ dan $\Lambda_{y}$ merupakan matrik loading yang menggambarkan koefisien regresi sederhana yang menghubungkan variabel laten dengan indikatornya. Residual yang diukur dengan $\varepsilon_{x}$ dan $\varepsilon_{y}$ dapat diinterpretasikan sebagai kesalahan pengukuran atau noise.

Blok dengan indikator formatif dapat ditulis persamaannya sebagai berikut:

$$
\begin{aligned}
& \xi=\Pi_{\xi} x+\delta_{\xi} \\
& \eta=\Pi_{\eta} y+\delta_{\eta}
\end{aligned}
$$

Dimana $\xi, \eta, x$ dan y adalah indikator atau manifest variabel untuk variabel laten endogen dan eksogen. $\Pi_{\xi}$ dan $\Pi_{\eta}$ adalah koefisien regresi berganda dari variabel laten dan blok indikator. $\delta_{\xi}$ dan $\delta_{\eta}$ adalah residual dari regresi

\section{Kerangka Pemikiran Teoritis}

Kerangka pemikiran merupakan model konseptual tentang bagaimana teori berhubungan dengan berbagai faktor yang telah diidentifikasi sebagai masalah yang penting. Kerangka pemikiran yang terbaik akan menjelaskan secara teoritis pertautan antara variabel yang akan diteliti. Jadi, secara teoritis perlu dijelaskan hubungan antara variabel bebas (independen) dengan variabel terikat (dependen). Berdasarkan landasan teori diatas dapat disusun suatu kerangka pemikiran sebagai berikut:

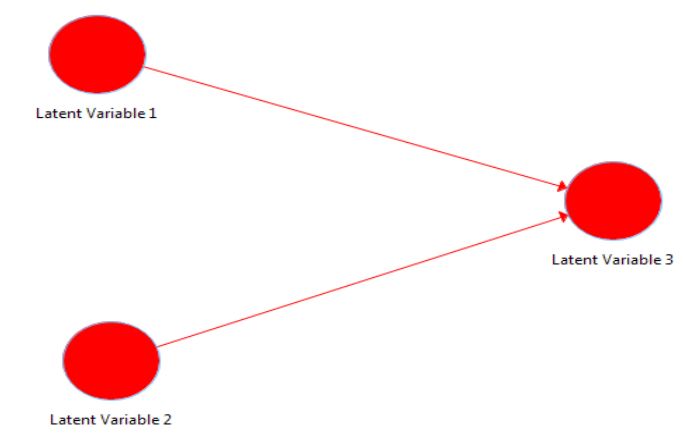

Gambar 1. Kerangka Pemikiran Kepuasan

Keterangan :

Latent Variabel 1 : Kualitas Produk

Latent Variabel 2 : Kualitas Pelayanan

Latent Variabel 3 : Kepuasan Pelanggan 


\section{HASIL DAN PEMBAHASAN}

\section{Konstruksi Diagram Jalur}

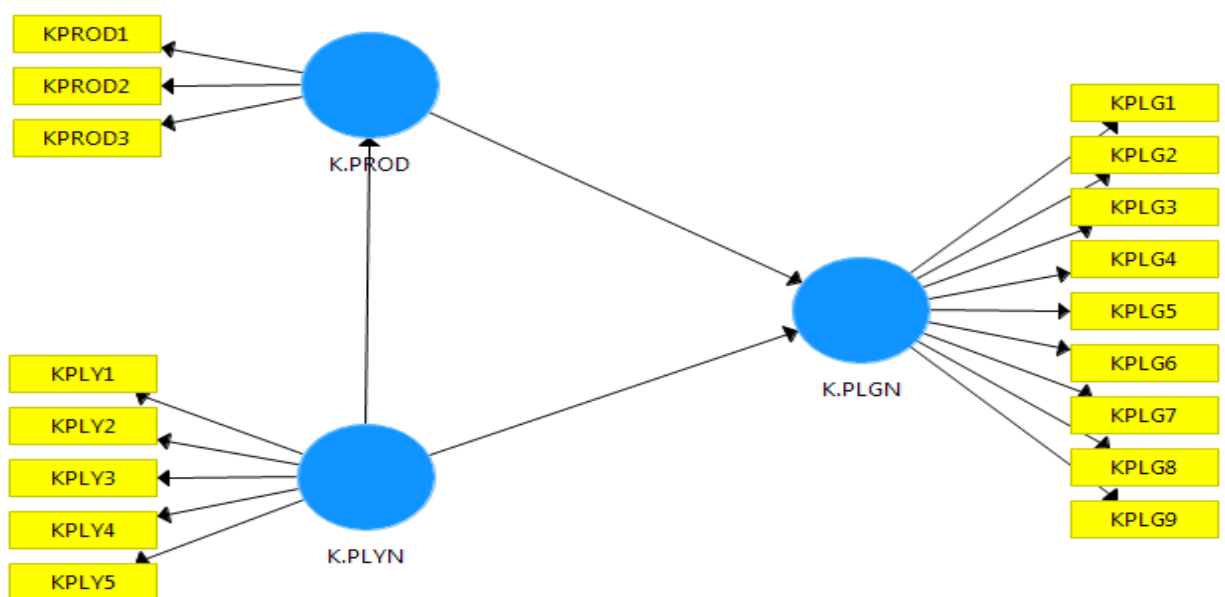

\section{Gambar 2. Diagram Jalur Data Kepuasan Pelanggan}

Tujuan dari analisis ini adalah untuk menguji apakah terdapat pengaruh tidak langsung dari variabel terhadap kepuasan pelanggan serta pengaruh variabel terhadap kepuasan pelanggan. Dalam penelitian ini digunakan partial least square untuk menguji data yang dikumpulkan dari 33 responden.

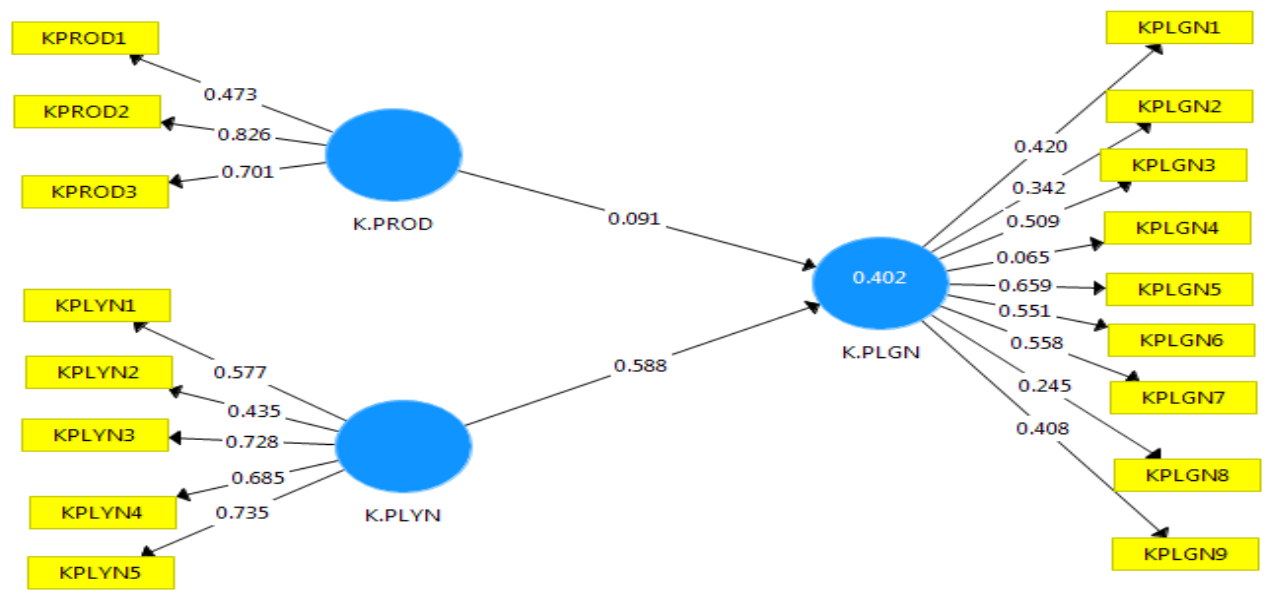

\section{Gambar 3. Diagram Jalur Hasil Output PLS}

Dari gambar 3 dapat dilihat nilai-nilai dari indikator terhadap variabel laten, misalnya pada variabel kualitas produk, indikator performance adalah yang paling berpengaruh yaitu sebesar 0.826 dan yang paling tidak berpengaruh adalah indikator design yaitu sebesar 0,473 yang berarti indikator performance adalah indikator yang sangat berpengaruh terhadap kepuasan pelanggan dibanding design atau conformance. Atau jika di hitung dengan menggunakan koefisien determinasi, indikator performance berpengaruh 82,6\% dan design sebesar 47,3\% terhadap kepuasan pelanggan.

Dari hasil analisis diperoleh nilai path Coefficient kualitas pelayanan sebesar 0,588 $(58,8 \%)$ dan kualitas produk 0,091 $(9,1 \%)$ berpengaruh terhadap kepuasan pelanggan.

Tabel 2. Nilai cross loading indikator 


\begin{tabular}{|c|c|c|}
\hline PEUBAH LATEN & INDIKATOR & $\begin{array}{c}\text { NILAI } \\
\text { CROSS LOADING }\end{array}$ \\
\hline \multirow[t]{9}{*}{ K. PLGN } & KPLGN1 & 0,420 \\
\hline & KPLGN2 & 0,342 \\
\hline & KPLGN3 & 0,509 \\
\hline & KPLGN4 & 0,065 \\
\hline & KPLGN5 & 0,659 \\
\hline & KPLGN6 & 0,551 \\
\hline & KPLGN7 & 0,558 \\
\hline & KPLGN8 & 0,245 \\
\hline & KPLGN9 & 0,408 \\
\hline \multirow[t]{5}{*}{ K.PLYN } & KPLYN1 & 0,232 \\
\hline & KPLYN2 & 0,395 \\
\hline & KPLYN3 & 0,360 \\
\hline & KPLYN4 & 0,552 \\
\hline & KPLYN5 & 0,296 \\
\hline \multirow[t]{3}{*}{ K. PROD } & KPROD1 & 0,170 \\
\hline & KPROD2 & 0,317 \\
\hline & KPROD3 & 0,209 \\
\hline
\end{tabular}

Dari table di atas terlihat bahwa setiap korelasi variabel dengan indikatornya lebih tinggi dibandingkan dengan korelasi variabel dengan indikator yang lainnya. Hal ini menunjukkan bahwa variable laten yaitu kepuasan pelanggan memprediksi indikator-indikator pada blok mereka lebih baik dibandingkan dengan indikator- indikator pada blok lainnya.

Dari hasil analisis diperole nilai akar AVE > 0,5 ( kecuali variabel Kepuasan Pelanggan ) hal ini menunjukkan bahwa semua variabel dalam model yang diestimasi memenuhi kriteria discriminant validity. Selain itu nilai composite reliability dari setiap variable $>0,70(70 \%)$ dengan demikian dapat disimpulkan bahwa semua variable mempunyai reabilitas yang baik dan nilai rHo A dari setiap variable > 0,70 (70\%) dengan demikian dapat disimpulkan bahwa semua variable mempunyai nilai konsistensi yang cukup baik.

Nilai R Square dari seluruh variabel independen sebesar 0,402 (40,2\%) terhadap kepuasan pelanggan, dengan demikian dapat disimpulkan bahwa variabel yang di pakai mempunyai pengaruh yang cukup baik. Sementara itu nilai VIF dari seluruh variabel independen di bawah 5 terhadap kepuasan pelanggan, dengan demikian dapat disimpulkan bahwa variabel yang di pakai mempunyai nilai koleniaritas yang cukup baik.

\section{KESIMPULAN DAN SARAN}

\section{Kesimpulan}

Berdasarkan hasil perhitungan yang diperoleh dalam penelitian ini, maka pada penelitian ini dapat disimpulkan beberapa hal yaitu : Kualitas produk berpengaruh terhadap kepuasan pelanggan yang artinya tidak semua pelanggan akan merasa puas jika hanya dengan kualitas produk, melainkan harus ada faktor lain. Pada penelitian ini indikator yang paling berpengaruh positif terhadap kualitas produksi sehingga kepuasan pelanggan dapat tercapai adalah indikator performance. Sedangkan indikator yang kurang berpengaruh terhadap kualitas produksi sehingga menyebabkan kepuasan pelanggan kurang tercapai adalah indikator design. 
Kualitas pelayanan berpengaruh terhadap kepuasan pelanggan yang artinya semakin tinggi dan baik kualitas pelayanan yang diberikan maka bisa di pastikan kepuasan pelanggan dapat tercapai. Indikator yang paling berpengaruh positif pertama terhadap kualitas pelayanan sehingga kepuasan pelanggan dapat tercapai adalah indikator assurance. Dan indikator yang kurang berpengaruh terhadap kualitas produksi sehingga menyebabkan kepuasan pelanggan kurang tercapai adalah indikator emphaty.

Kualitas produk dan pelayanan pelanggan secara bersamaan dapat berpengaruh terhadap kepuasan pelanggan sehinga jika kedua variabel ini di utamakan, maka kepuasan pelanggan akan tercapai lebih maksimal. Kualitas produk dan pelayanan pelanggan yang di ukur menggunakan indikator design, performance, conformance, tangiable, emphaty, responsiveness, reliability, assurance merupakan faktor-faktor yang mempengaruhi kepuasan pelanggan.

\section{Saran}

Pada penelitian selanjutnya, agar SEM-PLS dapat digunakan sebagai metode penelitian yang tidak membutuhkan sampel terlalu besar dalam kasus berbeda dan data tidak harus berdistribusi normal. Selain itu, metode SEM-PLS dapat juga dibandingkan dengan metode analisis SEM yang berbasis varian lainnya.

\section{UCAPAN TERIMA KASIH}

Terima kasih kepada seluruh jajaran Program Studi Matematika Fakultas MIPA Universitas Pamulang dalam menunjang pelaksanaan penelitian ini.

\section{REFERENSI}

Ghozali, I, 2008, Structural Equation Modelling-Metode Alternatif dengan PLS ed.2, Semarang: Badan Penerbit UNDIP.

Ghozali I, Fuad, 2008, Structural Equation Modelling-Teori, Konsep, dan Aplikasi dengan program Lisrell 8.80 ed.2, Semarang: Badan Penerbit UNDIP.

Mahfud. Sholihin, Pph.D \& Dr. Dwi Ratmono, 2013, Analisis SEM-PLS dengan SmartPLS 3.0 untuk hubungan nonlinier dalam penelitian Sosial dan Bisnis, Yogyakarta: Penerbit Andi Yogyakarta.

Makmur, http://masud.lecture.ub.ac.id/files/2015/05/14.-PLS.pdf, diakses tanggal 13 Agustus 2016.

Sudjana, Prof, Dr. Metode Statistika, Bandung: Penerbit Tarsito Bandung.

Sugiyono dan Wibowo, 2002, Statistik Penelitian Edisi 1, Bandung: Alfabeta. 